\title{
Summertime thermohaline structure of the Brazil Current Region between Santos (SP) and Rio de Janeiro (RJ)
}

\author{
Edmo José Dias CAMPOS, Sueli Susana de GODOI, Yoshimine IKEDA, Luis Vianna NONATO \& \\ José E. GONÇALVES
}

Instituto Oceanográfico da Universidade de Sāo Paulo

(Caixa Postal 66149, 05389-970 São Paulo, SP, Brasil)

\begin{abstract}
- Abstract: Within the scope of the MAR-14 Project, part of the Brazil-Germany Bilateral Agreement in Marine Sciences, an oceanographic survey aboard the R/V Victor Hensen was carried out in Brazilian coastal waters between Santos $\left(23^{\circ} 56^{\prime} \mathrm{S}\right)$ and Rio de Janeiro $\left(22^{\circ} 54^{\prime}\right.$ 'S), from January 15 to January 22,1991 . In this article we report results of preliminary analyses of the hydrographic data collected with CTD, STD, Nansen bottles and XBT's. These preliminary results show intense stratification in the first $200 \mathrm{~m}$ depth, and the penetration of the Brazil Current deep into the continental shelf region. Two eddy-like features were detected. The first one, anticyclonic, was located in the northern part of the domain and confined to the uppermost $200 \mathrm{~m}$. The second, a cyclonic vortex, was found a little to the southwest below $200 \mathrm{~m}$ and extending downwards to about $800 \mathrm{~m}$ depth. Water mass analyses based on T-S diagrams suggest that the interface between the South Atlantic Central Water (SACW) and the Antarctic Intermediate Water (AIW) is located at about $500 \mathrm{~m}$ depth. One important aspect of this study is that this was the first time a high resolution survey with a CTD probe was realized along the eastern Brasilian Coast, south of Cabo Frio.
\end{abstract}

- Resumo: Como parte do projeto MAR-14, componente do Acordo Bilateral Brasil-Alemanha em Ciências Marinhas, uma campanha oceanográfica a bordo do R/V Victor Hensen foi realizada em águas costeiras do Brasil entre Santos (23⒌' $\mathrm{S})$, de 15 a 22 de janeiro de 991 . Neste artigo reportamos resultados de análises preliminares dos dados hidrográficos coletados com o auxlio de CTD, STD, garrafas de Nansen e XBT's. Esses resultados preliminares mostram uma intensa estratificação nos primeiros $200 \mathrm{~m}$ de profundidade, e a penetração da corrente bem adentro da regiāo sobre a plataforma continental. Duas estruturas com características de vórtices de meso-escala foram detectadas. O primeiro, anticiclônico, estava localizado na parte norte da rede de estaçōes e confinado praticamente nos primeiros $200 \mathrm{~m}$ de profundidade. O Segundo, um vortice ciclônico, foi encontrado um pouco para o sudoeste e abaixo dos $200 \mathrm{~m}$, estendendo-se para baixo até cerca de 800 metros. Análises de Massa de água baseadas em diagramas T-S sugerem que a interface entre a Água Central do Atlântico Sul (ACAS) e a Água Intermediária Antártica (AIA) se encontrava em aproximadamente $500 \mathrm{~m}$ de profundidade. Um aspecto importante desse cruzeiro que deve ser ressaltado é que, esta foi a primeira vez em que um sensor do tipo CTD foi utilizado com essa resolução ao longo da costa leste do Brasil, abaixo de Cabo Frio.

- Descriptors: Brazil current, Thermohaline structure, Santos Bight.

- Descritores: Corrente do Brasil, Estrutura termohalina, Bacia de Santos.

\section{Introduction}

Compared to the Gulf Stream system in the North Atlantic, the Brazil Current, a poleward flow of warm water

Contr. no. 756 do Inst. oceanogr. da Usp. along the South American coastline, is poorly known. Indeed, much of what is known about the large scale of this southern Atlantic western boundary current is still today from the classical studies based on the Meteor expeditions (Wüst, 1935; Defant, 1941; Sverdrup et al., 1942). The water-mass structure, for instance, usually 
follows the classification by Sverdrup et al. (1942), based on the Meteor oceanographic stations. Relatively, very few works focusing on the large-scale have been carried out since then (e.g., Stramma, 1989; Garfield III, 1990).

Focusing on the meso-scale, however, a greater number of hydrographic surveys has been completed during the last two decades. Among them are the works of Signorini $(1976,1978)$, Miranda \& Castro Filho $(1979,1982)$, Evans et al. (1983), Miranda (1985) and Signorini et al. (1989). The great majority of these works, though, concentrates basically in the region between Cabo de São Tomé and Rio de Janeiro. From the works cited, for instance, only Miranda (1985) includes hydrographic stations down to the region of Ilha de São Sebastiāo. Between this latitude and Cabo de Santa Marta, there is a shortage not only of scientific publications, but even of hydrographic data available.

In this article we present the preliminary results of analyses carried out with data collected between Rio de Janeiro (RJ) and Santos (SP), during a cruise aboard the R/V Victor Hensen, of the Alfred Wegener Institute (Germany), from 01/15 to 01/22/91. This cruise, part of the MAR-14 Project (Brazil-Germany Marine Sciences Agreement), was performed along four transects between the $100 \mathrm{~m}$ and $2400 \mathrm{~m}$ isobaths, and along three sections oriented parallel to the isobaths (Fig. 1).

\section{The Brazil Current between Cabo de São Tomé and Rio de Janeiro}

Most of the observational work in the past two decades, either by Brazilian or international oceanographers, has focused mainly on the Cabo Frio Region, probably because of the intense upwelling observed there, and some other characteristics, such as: the strong bottom topography gradient; the vicinity of the Brazil Current; and the change in direction of the coastline, from predominantly N-S to approximately E-W. According to some of these studies, the mass transport by the Brazil Current is much weaker than one would expect, based on the classical Sverdrup balance: the equatorward drift in the interior of the subtropical Atlantic ocean, would require a much stronger southward transport in the boundary current. Computations by Evenson and Veronis (1975) based on the Hellerman and Rosenstein (1983) wind stress curl distribution indicate that up to $30 \mathrm{~Sv}\left(30 \times 10^{6} \mathrm{~m}^{3} \mathrm{~s}^{-1}\right)$ should flow in the Brazil Current near $30^{\circ} \mathrm{S}$, and about $20 \mathrm{~Sv}$ near $20^{\circ} \mathrm{S}$. This, however, is not confirmed by hydrographic observations, direct measurements nor computations by inverse methods.

Signorini (1978) and Miranda \& Castro Filho (1979) based on historical hydrographic data show that the total geostrophic transport cannot be higher than $9.4 \mathrm{~Sv}$ in the upper $600 \mathrm{~m}$. Direct measurements of the Brazil Current near $23^{\circ} \mathrm{S}$ show southward flow of warm water above 400 $\mathrm{m}$ and northward flow of AIW beneath. Transport in the upper layer is about $6 \mathrm{~Sv}$ to the south, offshore of the 200-m isobath (Evans \& Signorini, 1985). Calculations based on the inverse method by Fu (1981) indicate little transport north of $30^{\circ} \mathrm{S}$. Evans and Signorini (1985) studied the Brazil Current between $19^{\circ}$ and $24^{\circ} \mathrm{S}$ and found the Brazil Current confined to the region near the continental slope. Geostrophic calculations show transport below $10 \mathrm{~Sv}(3.8 \mathrm{~Sv}$. relative to $500 \mathrm{~m}$ and $6.8 \mathrm{~Sv}$. relative to $1000 \mathrm{~m}$ ).

With respect to the thermohaline structure, water mass analyses suggest a layered current system with warm water flowing southward over the northward-flowing Antarctic Intermediate Water (AIW) and, below that, the southward flowing North Atlantic Deep Water (NADW) and the Antarctic Bottom Water (ABW) flowing to the north. This structure, associated with the best defined water masses of classical oceanography, is well accepted today. Signorini (1976) shows, in the region between Cabo de Sāo Tomé and Cabo Frio $\left(22^{\circ}-23.5^{\circ}\right)$, that the water-mass structure is formed by warm, high salinity surface water in the upper $200 \mathrm{~m}$; the South Atlantic Central Water (SACW) between $200 \mathrm{~m}$ and $600 \mathrm{~m}$; the northward-flowing AIW below that; and the NADW flowing to the south beneath the AIW. Miranda (1985) confirms that structure and suggests that only one water mass should be considered for the first $400-600 \mathrm{~m}$ depth, the SACW.

In order to obtain a better figure of the water mass structure in the region covered by the Victor Hensen cruise, we focus only on the thermohaline structure based on classical water mass analyses. A more detailed work including estimations of geostrophic currents, heat and mass transport are underway, and the results will be submitted for publication in the near future.

\section{Material and methods}

The data discussed in this article consist of a set of vertical profiles of temperature and salinity, collected at each one of the stations indicated in Figure 1. Basically, the data collection was made with a Seabird CTD, model SBE 9-17 and with XBT's, launched between alternate CTD stations with depths equal or greater than $500 \mathrm{~m}$. The spacing between two successive CTD station was 10 nautical miles and, in some of the CTD stations, STD and Nansen bottles equipped with reversing thermometers were used to collect data for checking the accuracy of the data acquired by the CTD. For technical reasons, the maximum depth of all stations was no greater than $950 \mathrm{~m}$. 


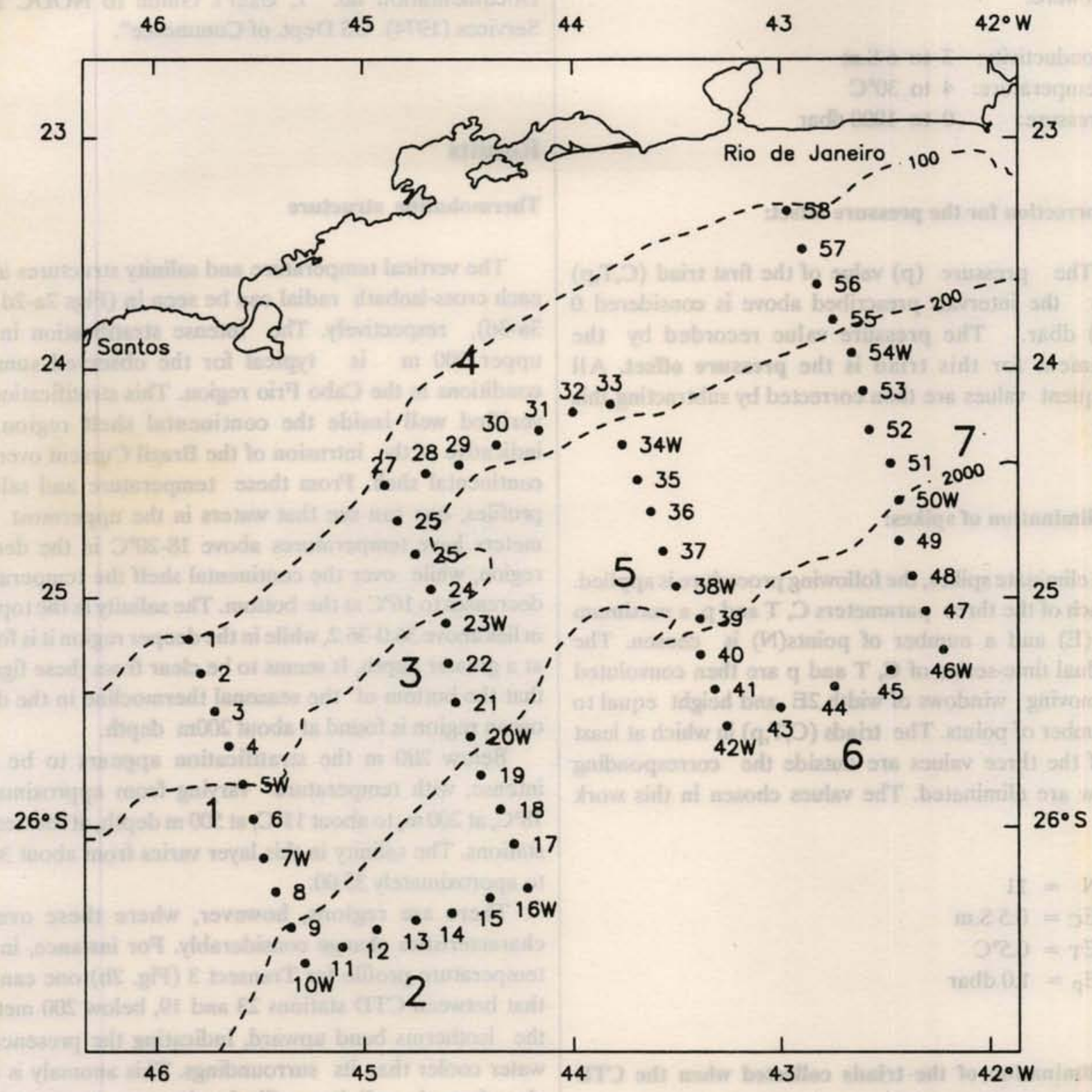

Fig. 1. Geographical location of 58 CTD stations during the MAR 14 Cruise aboard the RN Victor Hensen. Water mass analyses were carried out for stations labeled with $W$. The distance between two successive stations is about 10 nautical miles.

The type of CTD used in this survey has no way of being switched off after the maximum depth has been reached. As a result, it collects and stores internally data at a relatively high frequency rate while the instrument is in the water, up to its maximum data storage capacity. In normal use, each time the device is launched it usually collects much more information than is needed. To eliminate the undesirable data, some kind of filtering must be applied. In this study the data were filtered according to a methodology developed at the Institute für
Meereskunde under Universität zu Kiel (IfM-Kiel). This filtering process is done along the following steps:

\section{(i) Elimination of anomalous values:}

Certain intervals for the variation of the measured parameters (Conductivity, Temperature and Pressure) are adopted. If the value of any of the three elements of the triad $(C, T, p)$ is not within the imposed interval, the 
triad is neglected altogether. In this study the acceptable ranges were:

Conductivity: 3 to $6 \mathrm{~S} . \mathrm{m}$

Temperature: 4 to $30^{\circ} \mathrm{C}$

Pressure:

0 to $1000 \mathrm{dbar}$

\section{(ii) Correction for the pressure offset:}

The pressure (p) value of the first triad $(C, T, p)$ within the intervals prescribed above is considered 0 (zero) dbar. The pressure value recorded by the instrument for this triad is the pressure offset. All subsequent values are then corrected by subtracting this offset.

\section{(iii) Elimination of spikes:}

To eliminate spikes, the following procedure is applied. For each of the three parameters $\mathrm{C}, \mathrm{T}$ and $\mathrm{p}$, a maximum error $(E)$ and a number of points $(N)$ is chosen. The individual time-series of $\mathrm{C}, \mathrm{T}$ and $\mathrm{p}$ are then convoluted with moving windows of width $2 \mathrm{E}$ and height equal to the number of points. The triads $(C, T, p)$ in which at least one of the three values are outside the corresponding window are eliminated. The values chosen in this work were:

$$
\begin{aligned}
& \mathrm{N}=11 \\
& \mathrm{E}_{\mathrm{C}}=0.5 \mathrm{~S} . \mathrm{m} \\
& \mathrm{E}_{\mathrm{T}}=0.5^{\circ} \mathrm{C} \\
& \mathrm{E}_{\mathrm{p}}=1.0 \mathrm{dbar}
\end{aligned}
$$

(iv) Elimination of the triads collected when the CTD downward velocity was below a minimum value:

For each point, a polynomial of degree $\mathbf{n}$ is adjusted over the pressure values, considering the preceding (np-1)/2 and past (np-1)/2 values for $\mathrm{p}$. The derivative of this polynomial at the point is then calculated and, whenever this derivative is below a prefixed value $V_{\min }$, the triad $(C, T, p)$ is rejected out. Values adopted in this study are:

$$
\begin{aligned}
\mathrm{V}_{\min } & =0.25 \mathrm{~m} / \mathrm{s} \\
\mathrm{n} & =1 \\
\mathrm{np} & =11
\end{aligned}
$$

In addition to this basic filtering, a Lagrangean interpolation for pressure interval pre-determined $(0.5 \mathrm{~m})$ is made according to the methodology described in the document "Key to Oceanographic Record Documentation no. 1, User's Guide to NODC Data Services (1974). US Dept. of Commerce".

\section{Results}

\section{Thermohaline structure}

The vertical temperature and salinity structures along each cross-isobath radial can be seen in (Figs 2a-2d and 3a-3d), respectively. The intense stratification in the upper $200 \mathrm{~m}$ is typical for the observed summer conditions in the Cabo Frio region. This stratification is verified well inside the continental shelf region, an indicative of the intrusion of the Brazil Current over the continental shelf. From these temperature and salinity profiles, one can see that waters in the uppermost 200 meters have temperatures above $18-20^{\circ} \mathrm{C}$ in the deeper region, while over the continental shelf the temperature decreases to $16^{\circ} \mathrm{C}$ at the bottom. The salinity in the top 200 $\mathrm{m}$ lies above $36.0-36.2$, while in the deeper region it is found at a greater depth. It seems to be clear from these figures that the bottom of the seasonal thermocline in the deep ocean region is found at about $200 \mathrm{~m}$ depth.

Below $200 \mathrm{~m}$ the stratification appears to be less intense, with temperature varying from approximately $18^{\circ} \mathrm{C}$, at $200 \mathrm{~m}$, to about $11^{\circ} \mathrm{C}$, at $500 \mathrm{~m}$ depth, at the deeper stations. The salinity in this layer varies from about 36.00 to approximately 35.00 .

There are regions, however, where these overall characteristics change considerably. For instance, in the temperature profile for Transect 3 (Fig. $2 \mathrm{~b}$ ) one can see that between CTD stations 23 and 19, below 200 meters, the isotherms bend upward, indicating the presence of water cooler than its surroundings. This anomaly is also clear from the salinity profile for the same transect (Fig. 3b). Below $200 \mathrm{~m}$, between stations 23 and 19 , the water is less saline than in the outer region. Density computation shows that this lower temperature water, even though with lower salinity, is heavier than its surroundings. Assuming geostrophic balance, one can suggest the presence of a cyclonic vortex in this region, confirmed by the horizontal profiles, discussed below. Miranda et al. (1985) detected a similar structure from XBT data collected from during October 24-28, 1983, along a radial locaied roughly in the same region of our Transect 3 (a little to the south of Ilha Grande Bay). The presence of this cyclonic vortex in practically the same place, in different seasons of two years apart, can induce one to infer that it is a permanent or at the least, a frequent feature of the circulation in that region. 


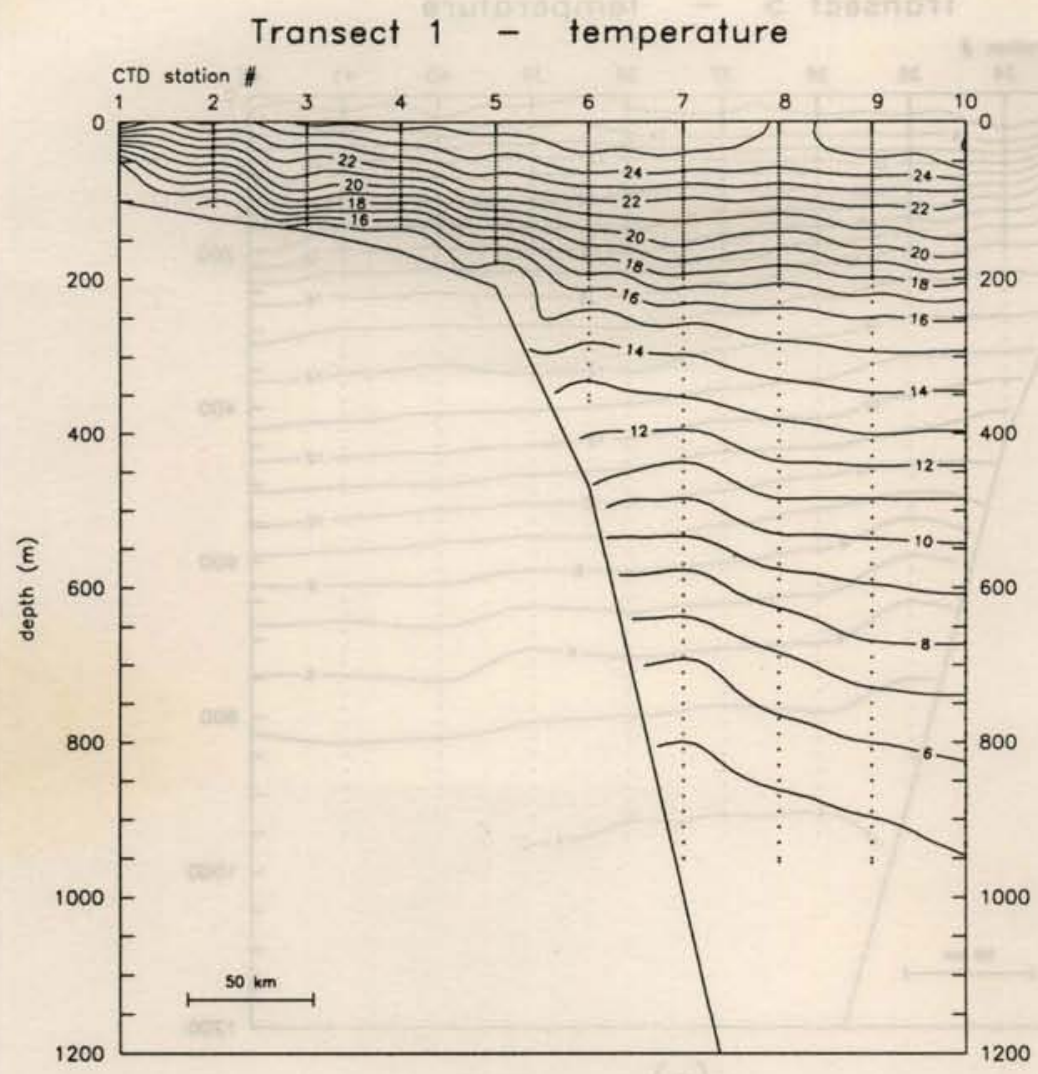

(a)

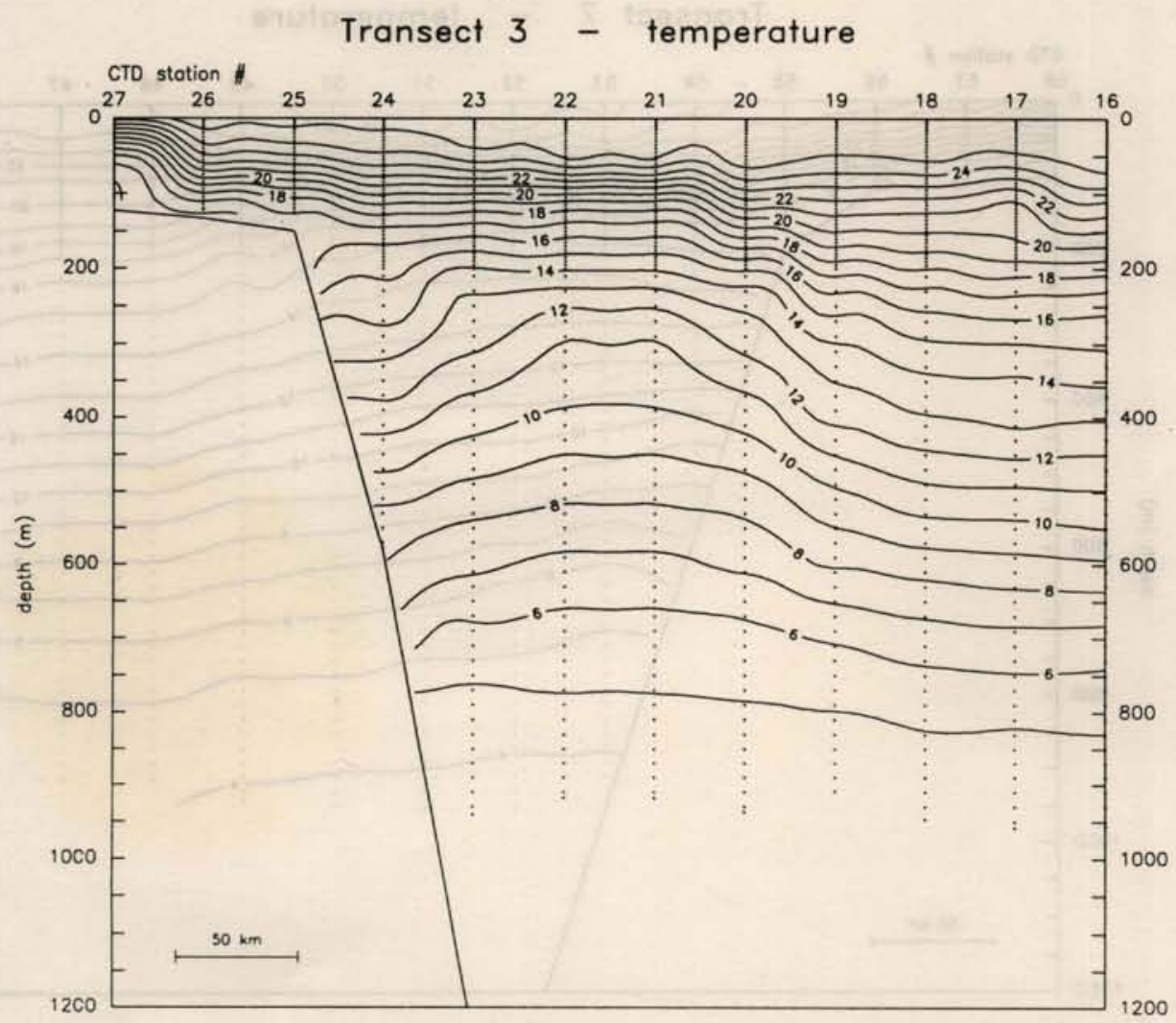

(b)

Fig. 2. Vertical profiles for Temperature along (a) Transect 1; (b) Transect 3;

(c) Transect 5; and (d) Transect 7. 


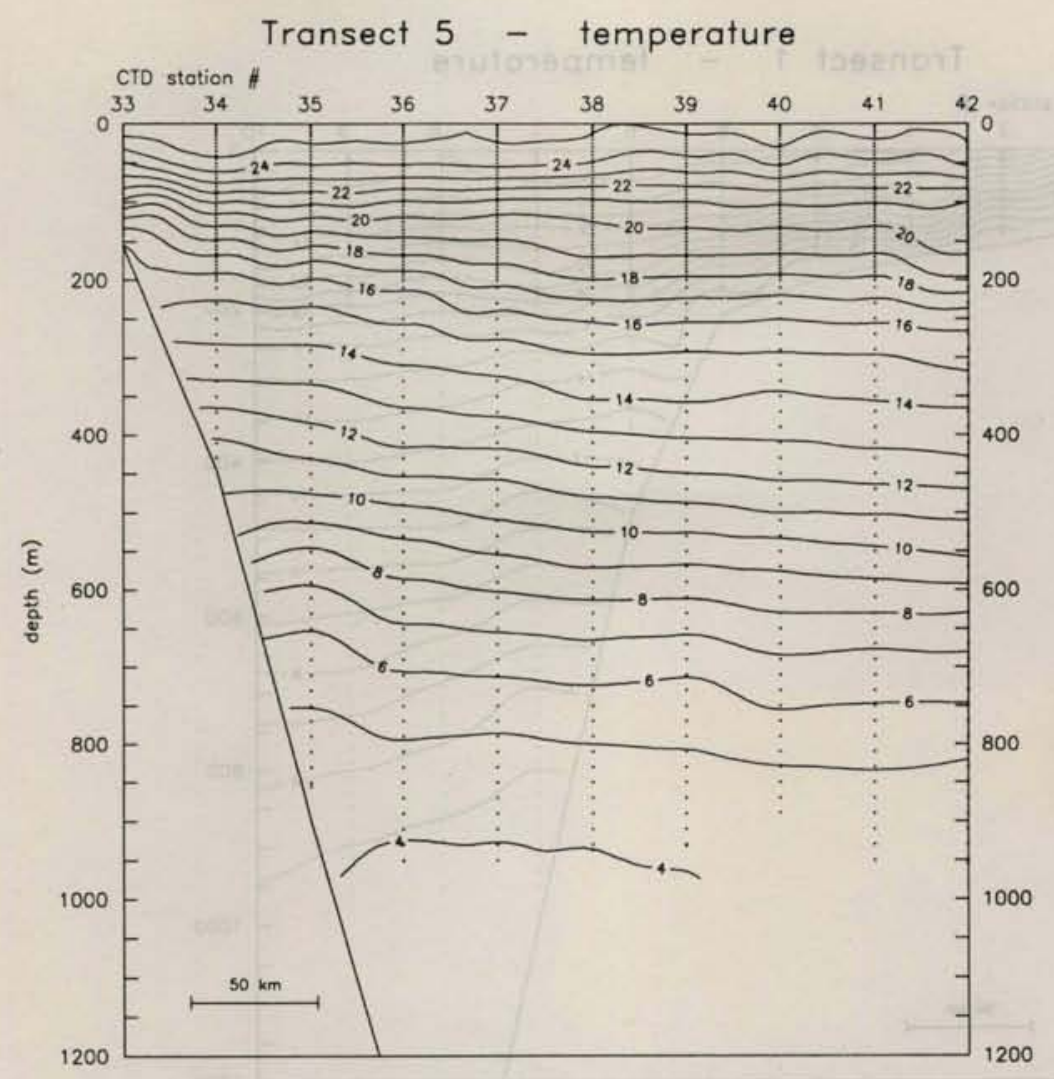

(c)

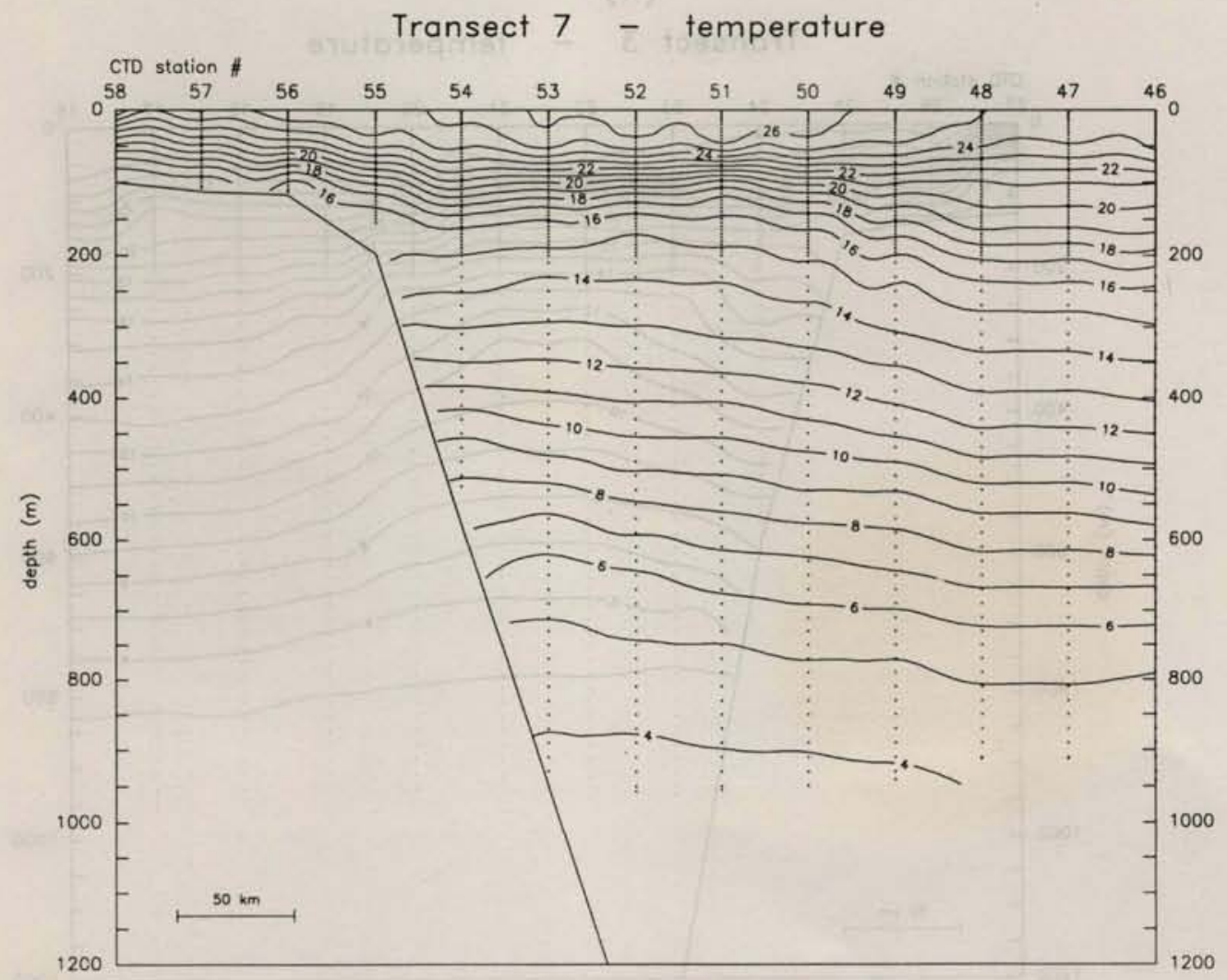

(d)

Fig. 2. Cont. 


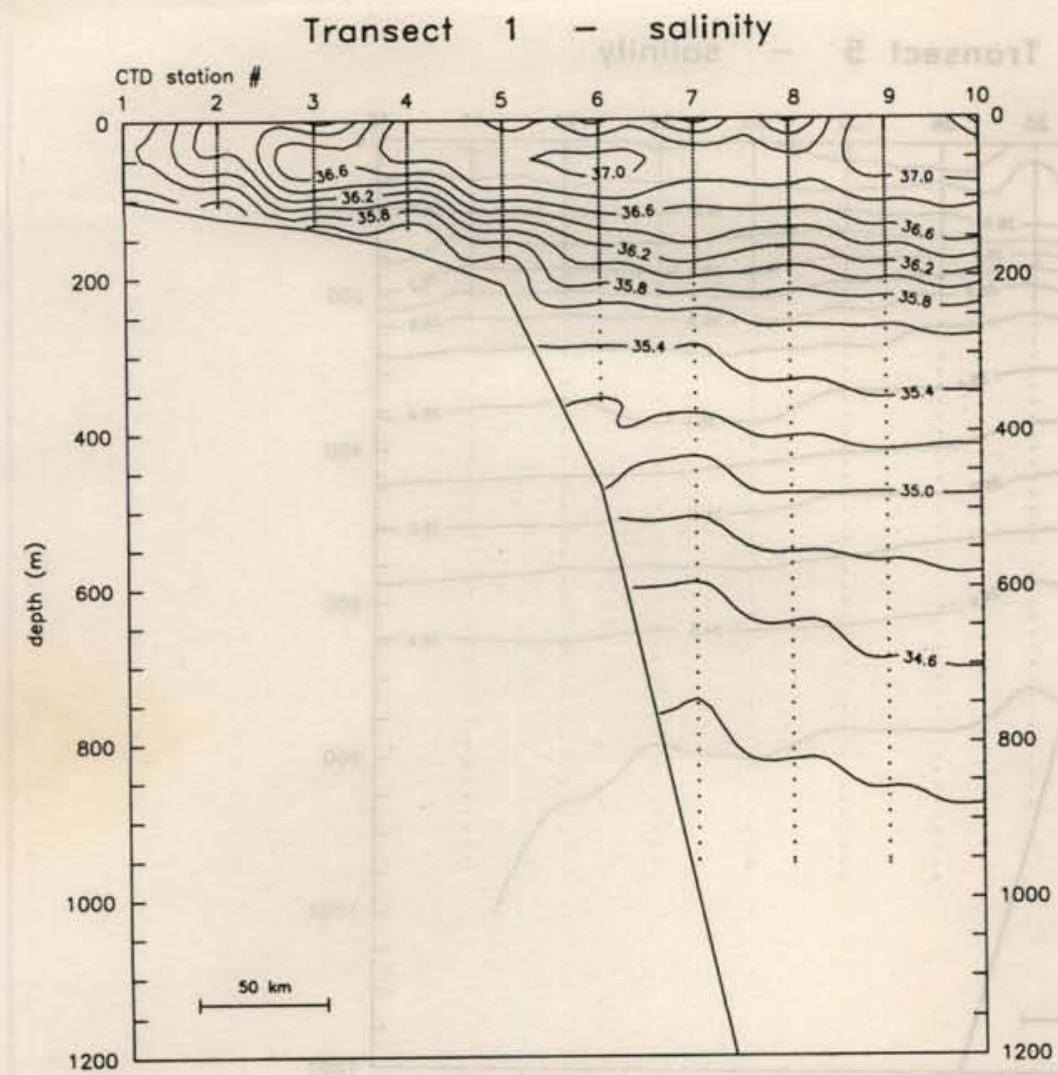

(a)

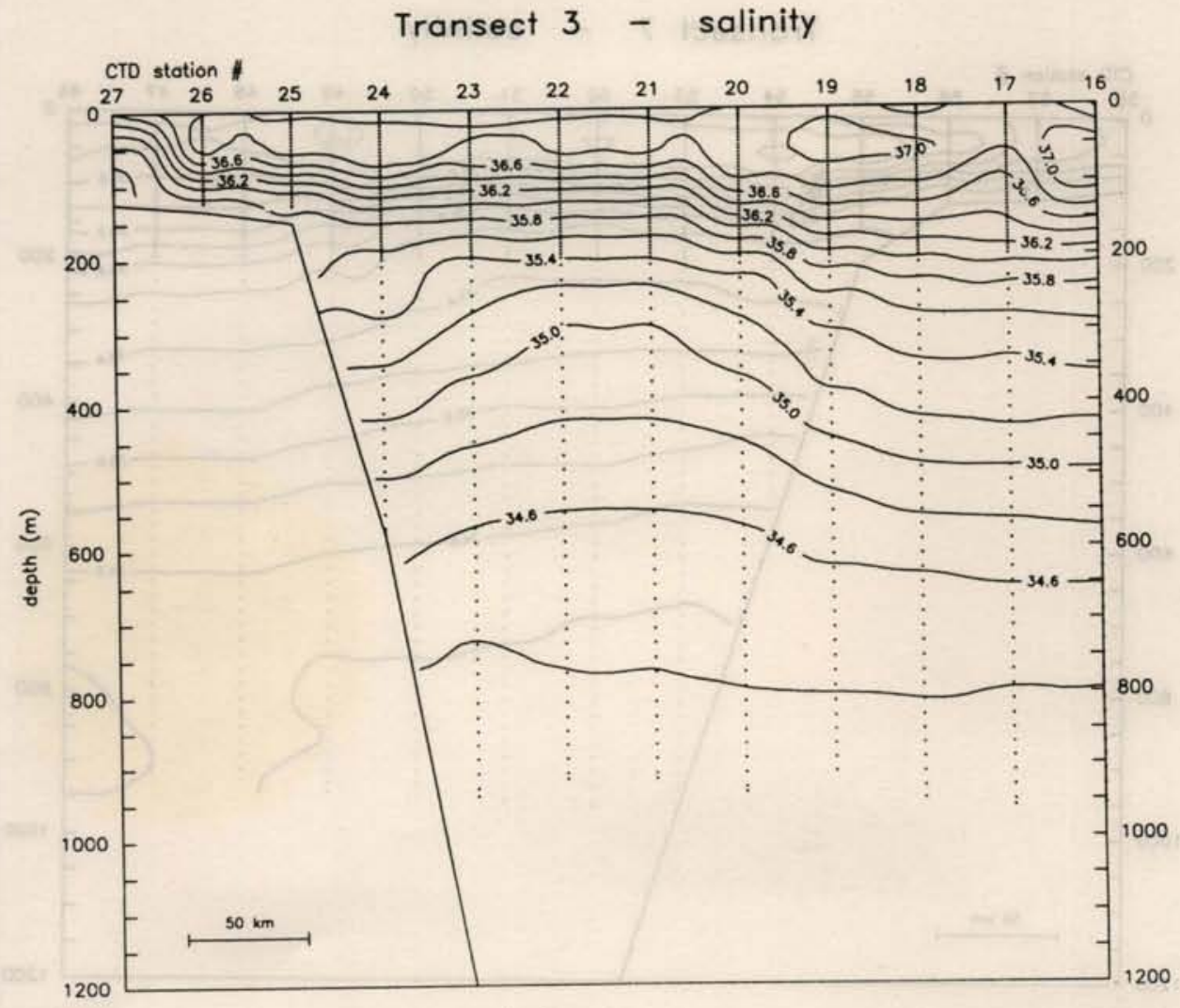

(b)

Fig. 3. Vertical profiles for Salinity along (a) Transect 1; (b) Transect 3;

(c) Transect 5; and (d) Transect 7. 


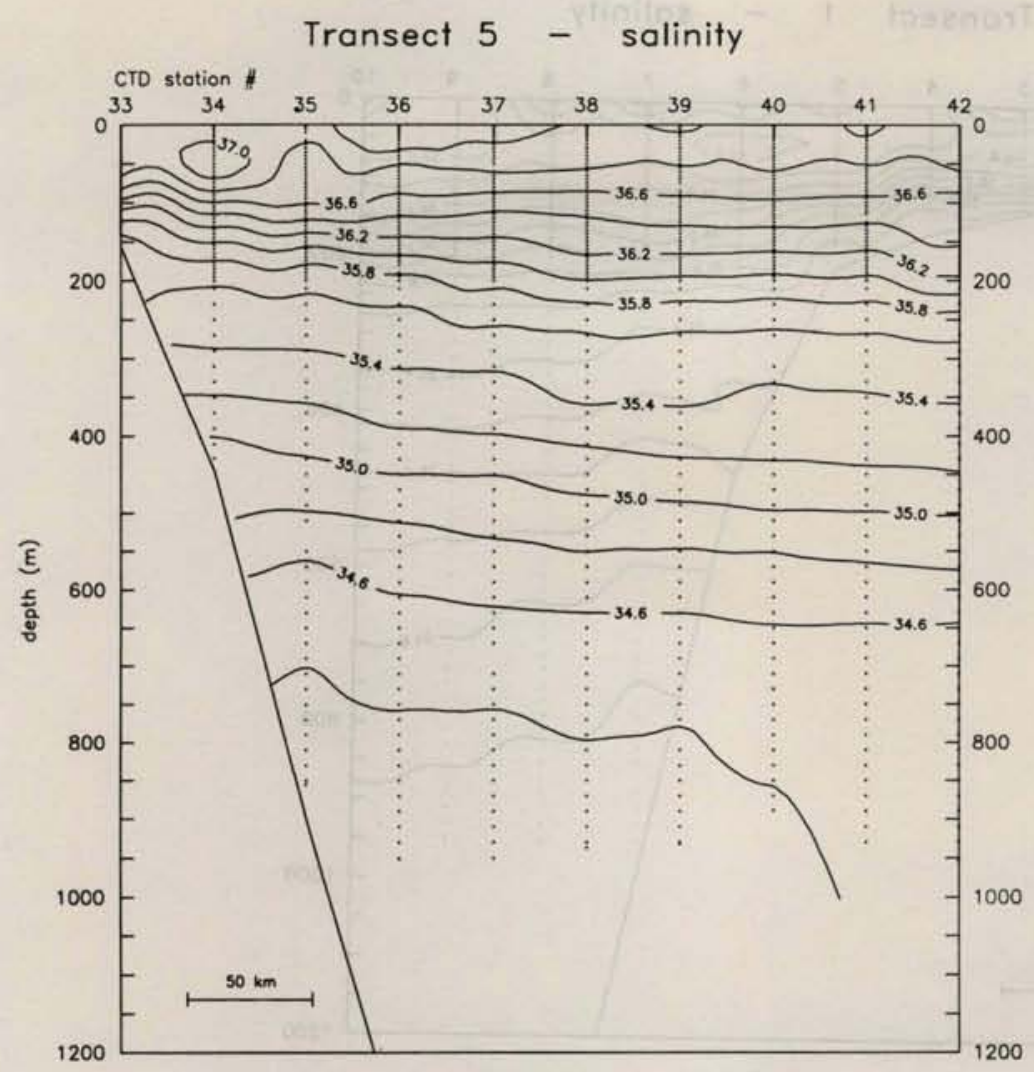

(c)

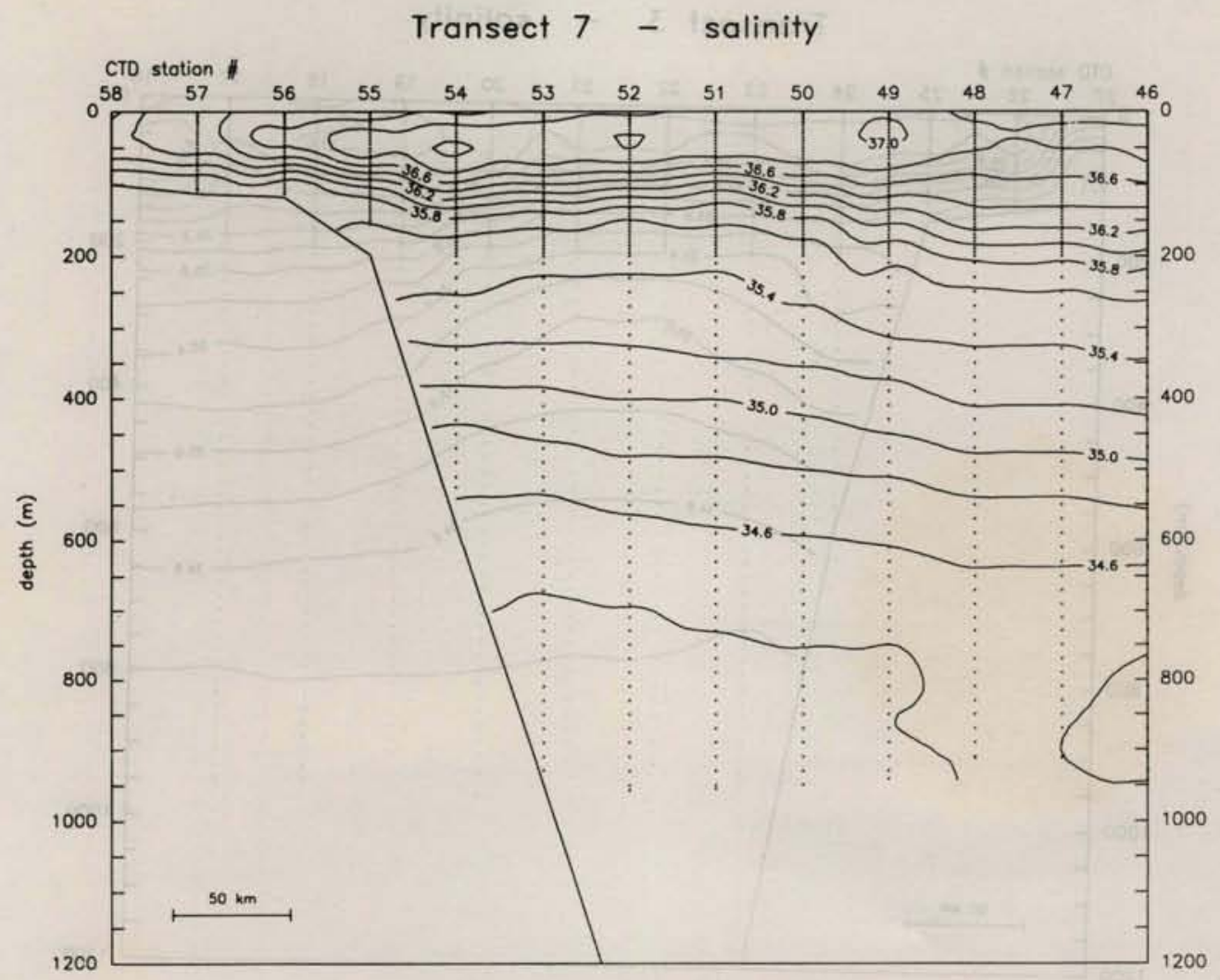

(d)

Fig. 3. Cont. 
Figures from $4 a$ to $4 d$ represent the horizontal temperature distributions at $0 \mathrm{~m}, 100 \mathrm{~m}, 200 \mathrm{~m}$ and $400 \mathrm{~m}$ levels, respectively. Figures $5 \mathrm{a}-5 \mathrm{~d}$ are the same for salinity and Figures 6a-6d for density. Even though no dynamic computation is discussed in this paper, based on these horizontal profiles at least, an indication of the circulation in the region can be inferred.

The circulation in the upper $200 \mathrm{~m}$ seems to be dominated by strong meandering, in the northern part, with the presence of an anticyclonic vortex crossed by the northernmost radial (Transect 7). The signature of this warm core ring can be also detected in the vertical profiles of temperature and salinity for Transect 7 (Figs 2d and 3d). The vertical axis of this anticyclone is strongly tilted toward the coast, as one goes deeper. The core of the vortex, which is almost over the $2000 \mathrm{~m}$ isobath at the surface, retreats to almost the $200 \mathrm{~m}$ isobath at $100 \mathrm{~m}$ level. At $200 \mathrm{~m}$ this feature is no longer detected. To the south, the circulation in the first $200 \mathrm{~m}$ seems to be more or less oriented along the isobaths, with the exception of a strong anomaly slightly shifted to the southwest at $200 \mathrm{~m}$, indicative of the upper part of a subsurface cyclonic feature.

The horizontal profiles at the $400 \mathrm{~m}$ level suggest a meandering flow oriented southwestward, with the presence of a strong cyclonic vortex partially intercepted by Transect 3 , a feature also observed in the vertical profiles.

\section{Water mass analysis}

For each transect in Figure 1, three CTD stations were chosen for the water mass analysis. The first one is on the continental shelf $(200 \mathrm{~m})$, the second one approximately halfway between the first and the last of the leg, and the third one as the last station on each radial. These stations are labeled with the letter $\mathrm{W}$ in Figure 1. The T-S diagrams for the deep water stations, as expected, turn out to be very similar to each other. Figure 7, the T-S diagram for CTD station 23, is representative of these diagrams. Note that Figure 7 also shows the Shtokman's "triangle of mixing", used in the determination of the water mass interfaces.

Since the maximum depth of each station is not greater than $950 \mathrm{~m}$, in order to use the so called "triangle of mixing" technique (Shtokman, 1946) in the water mass analysis, we had to rely on the thermohaline indices found in the literature for the AIW and for the NADW. These indices, according to Mamayev (1975), are (2.2 $\left.2^{\circ}-33.8\right)$ and $\left(2.5^{\circ} \mathrm{C}, 34.9\right)$ for the AIW and NADW, respectively. The thermohaline index for the uppermost water mass was computed with the available data. For these values, however, a part of the T-S curve would be outside the triangle defined by the three indices. To avoid this, a slightly different value for the AIW salinity was considered (33.31 instead of 33.8).

Based on the T-S diagrams and the triangle of mixing calculations, one can suggest the following water mass structure.

- Seasonal Thermocline Water. Water with maximum average temperature and salinity $25.65^{\circ} \mathrm{C}$ and 37.01 near the surface (mixed layer), and with $\mathrm{T}$ and $\mathrm{S}$ decaying rapidly down to a depth dependent on the location. On the continental shelf this uppermost layer has a thickness of up to $110 \mathrm{~m}$, with increasing depth in the seaward direction. The maximum depth of the surface layer, $171 \mathrm{~m}$, is found at the southernmost CTD station (the last station on the southernmost radial). Its depth also increases from North to South. This water mass usually is also referred as Tropical Water (TW).

- SACW: Water with thermohaline indices $\left(20.0^{\circ}\right.$, 36.36). Below the mixed layer and the seasonal thermocline, this relatively warm and saline water can be found down to a depth of approximately $513 \mathrm{~m}$ (CTD station 42). This is in good agreement with the suggestion of Miranda (1985), that the interface between the SACW and the AIW should lie between 400 and $600 \mathrm{~m}$. The computed thermohaline index is also in good agreement with those found in the literature (e.g. Miranda, 1985). The interface between the mixed layer and the SACW is represented by the points " $A$ " in the T-S diagram shown in Figure 7.

- AIW. Applying the geometric rules of the triangle of mixing, the interface between the SACW and the AIW (point labeled " $D$ " in the T-S diagram of Fig. 7) was determined to be at an average depth of $500 \mathrm{~m}$ at the deeper stations, and at an average depth of $415 \mathrm{~m}$ at the shallower stations where this interface could be detected.

- NADW. Even though one expects to find the southward flowing North Atlantic Deep Water below the AIW, the interface between these two water masses could not be determined in this work, given the relative shallowness of the hydrographic stations. 


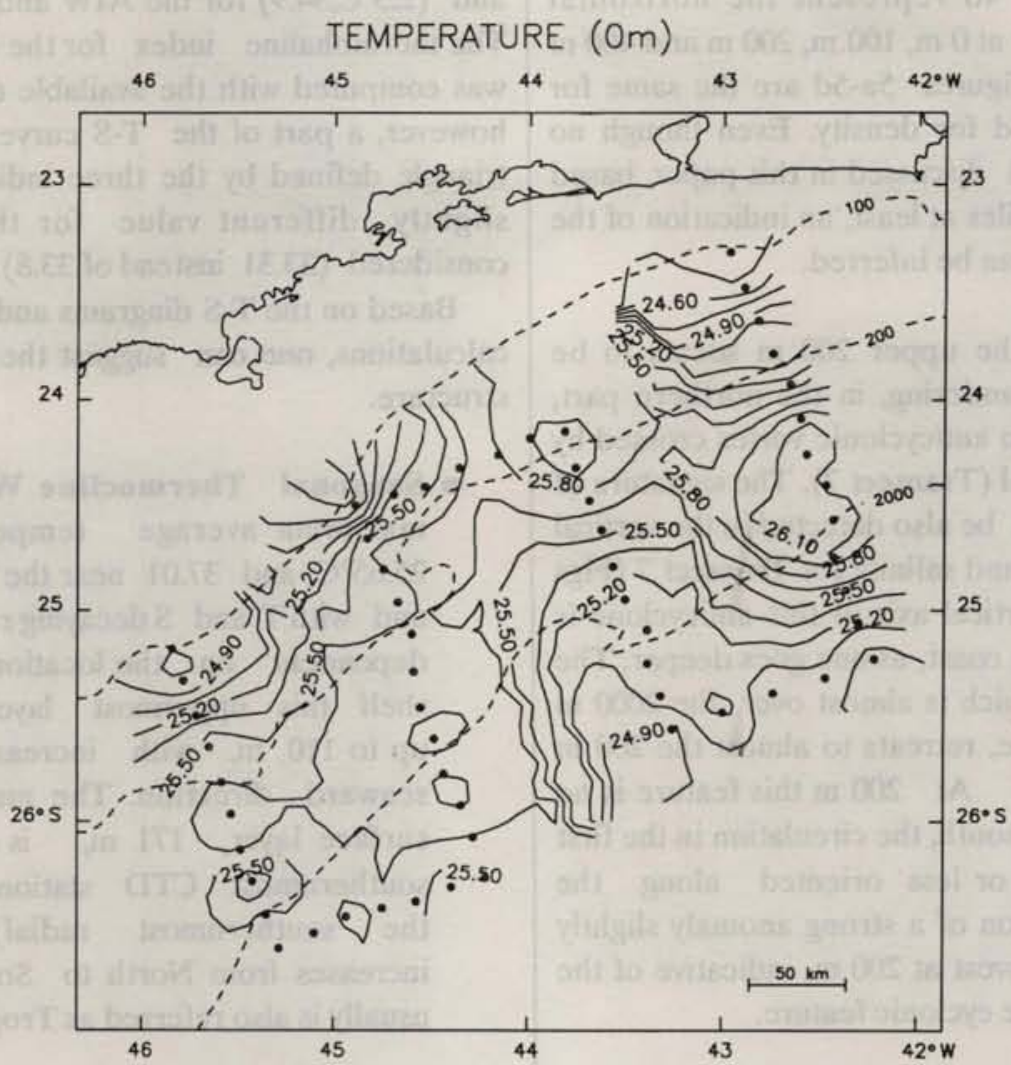

(a)

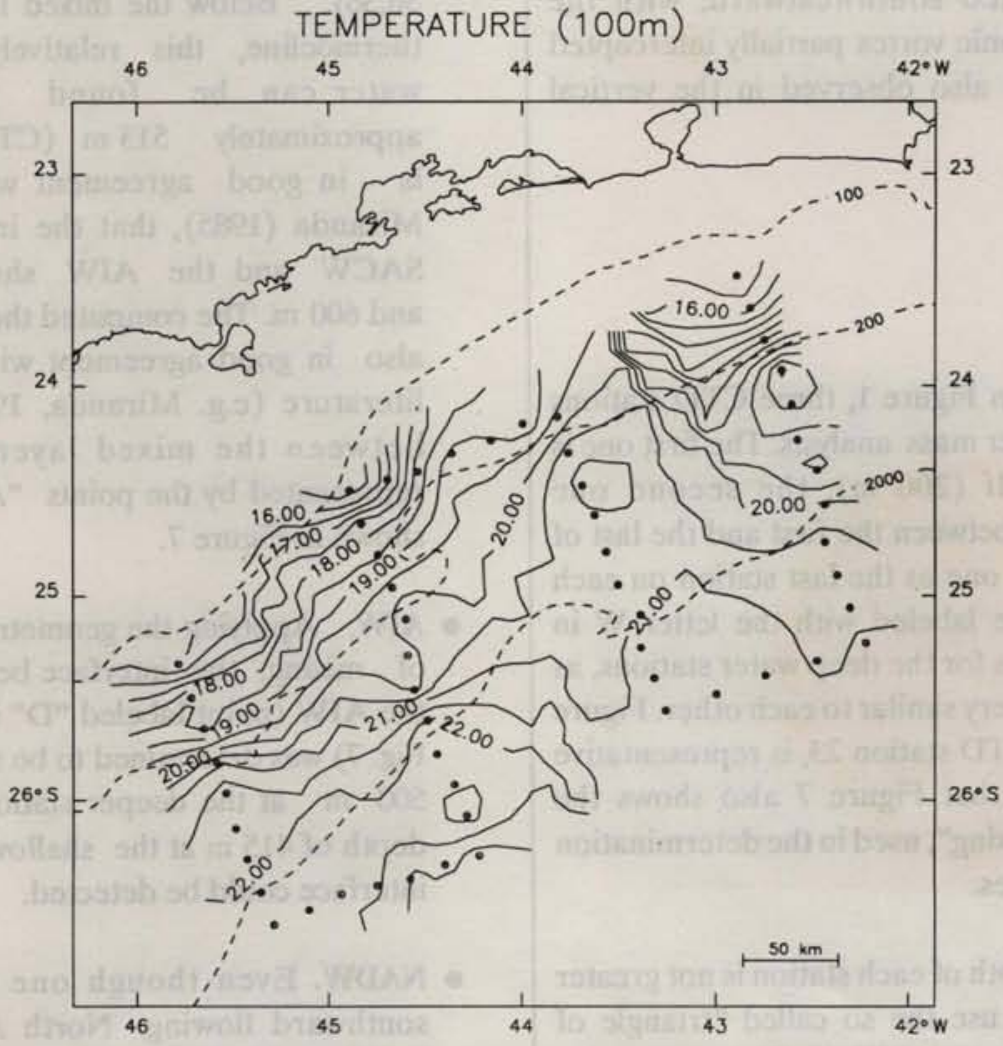

(b)

Fig. 4. Horizontal profiles for Temperature at (a) $0 \mathrm{~m}$; (b) $100 \mathrm{~m}$; (c) $200 \mathrm{~m}$; and (d) $400 \mathrm{~m}$. 


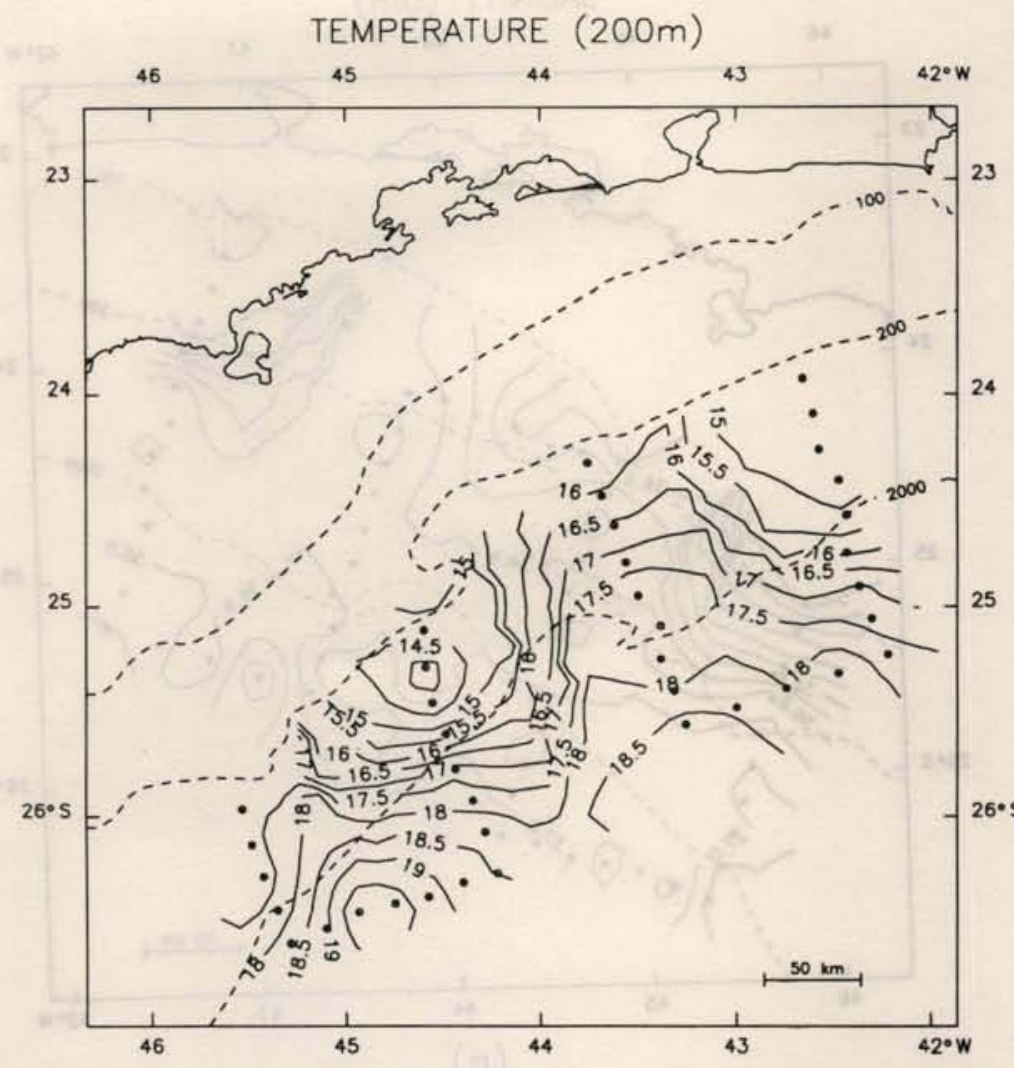

(c)

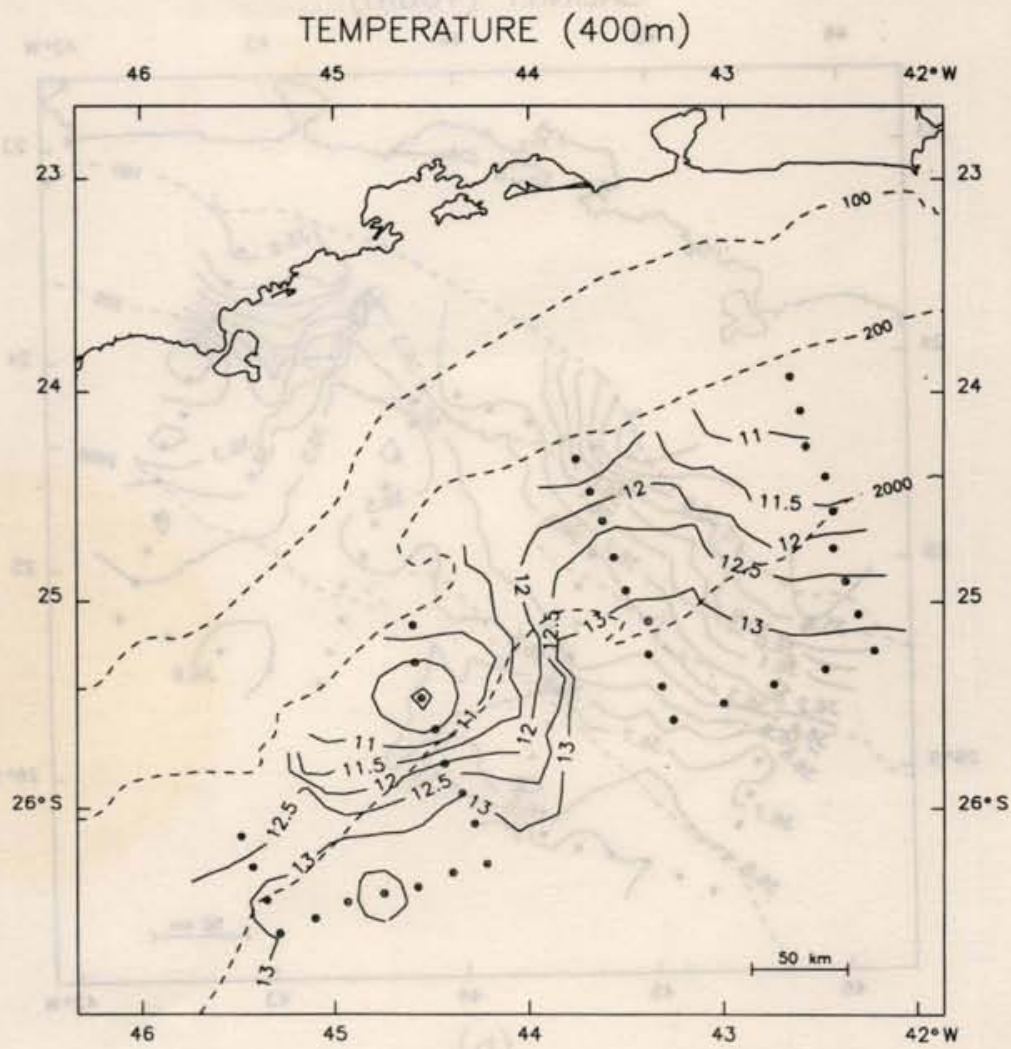

(d)

Fig. 4. Cont. 

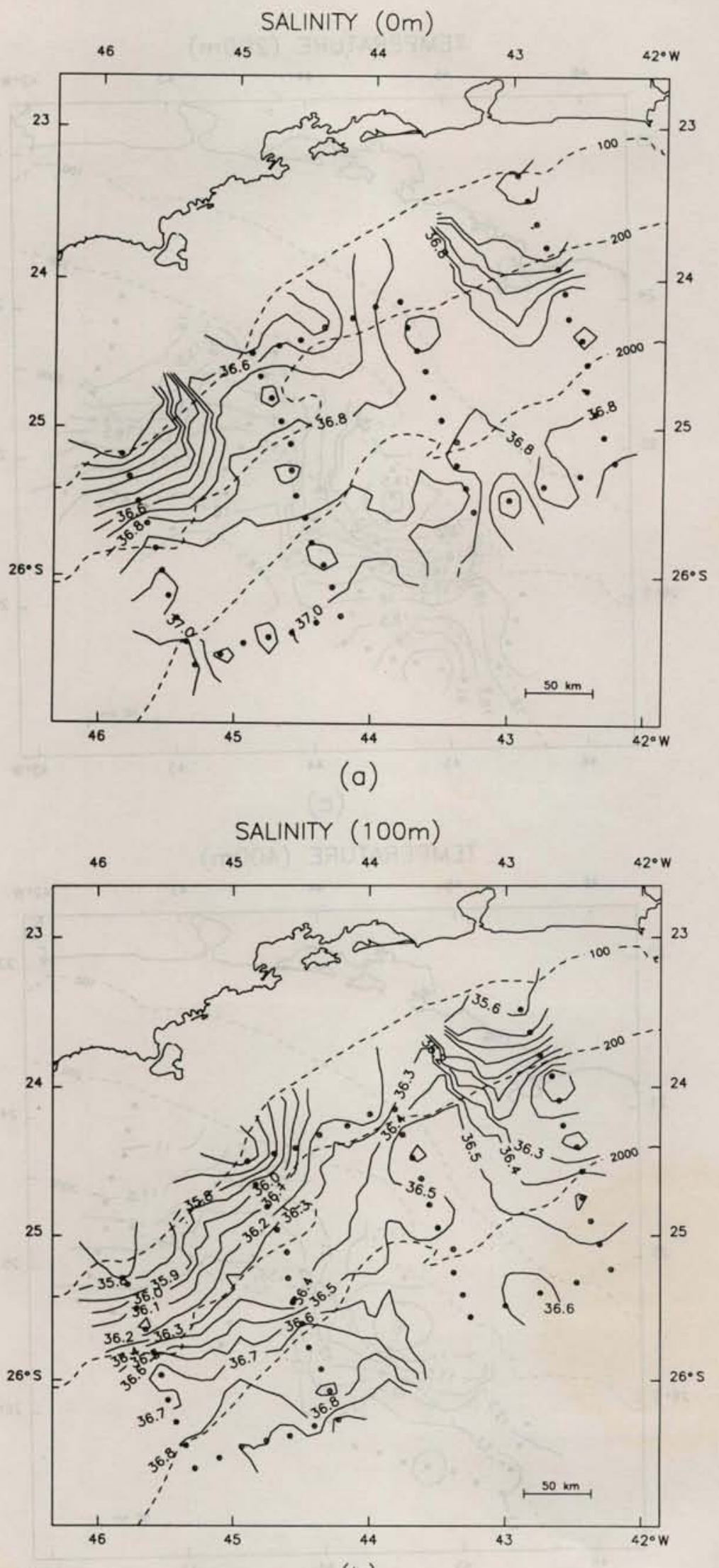

(b)

Fig. 5. Horizontal profiles for Salinity at (a) $0 \mathrm{~m}$; (b) $100 \mathrm{~m}$; (c) $200 \mathrm{~m}$; and (d) $400 \mathrm{~m}$. 


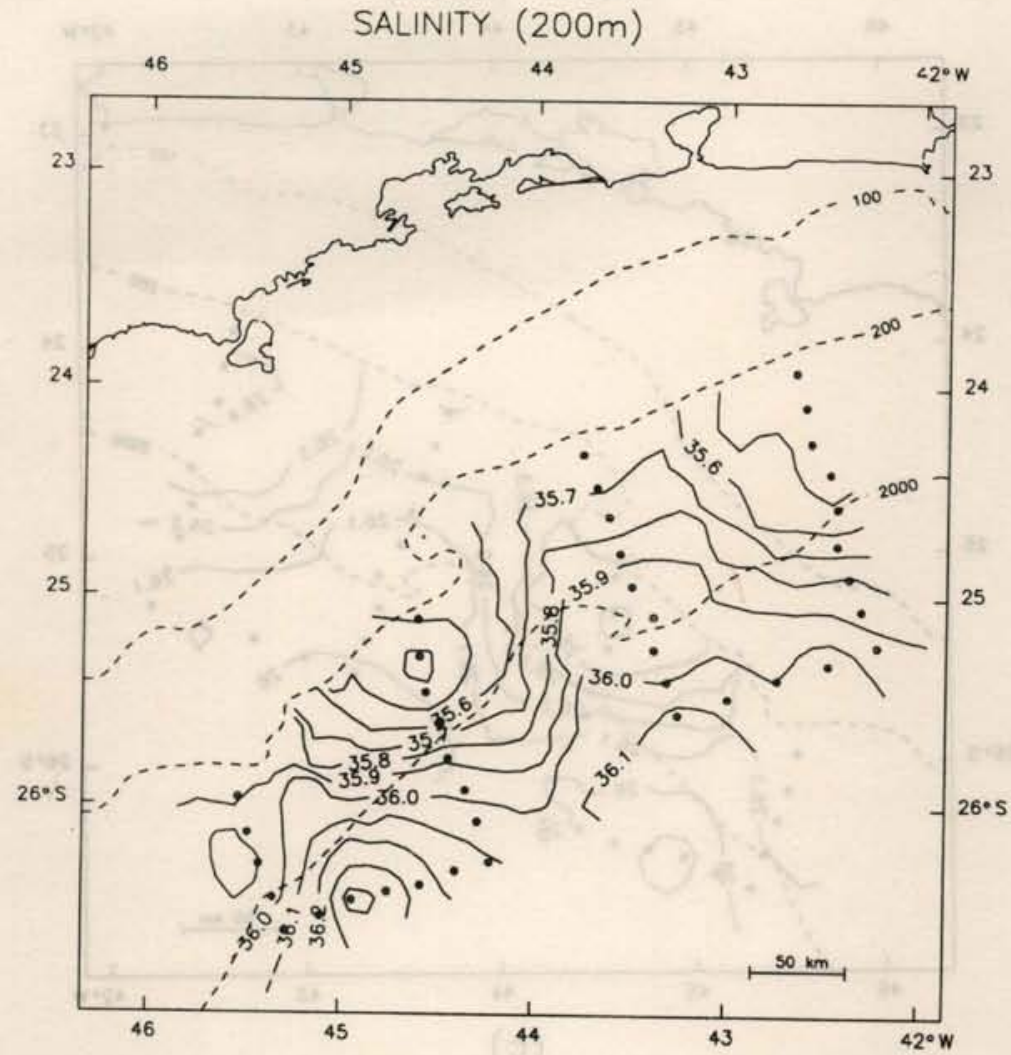

(c)

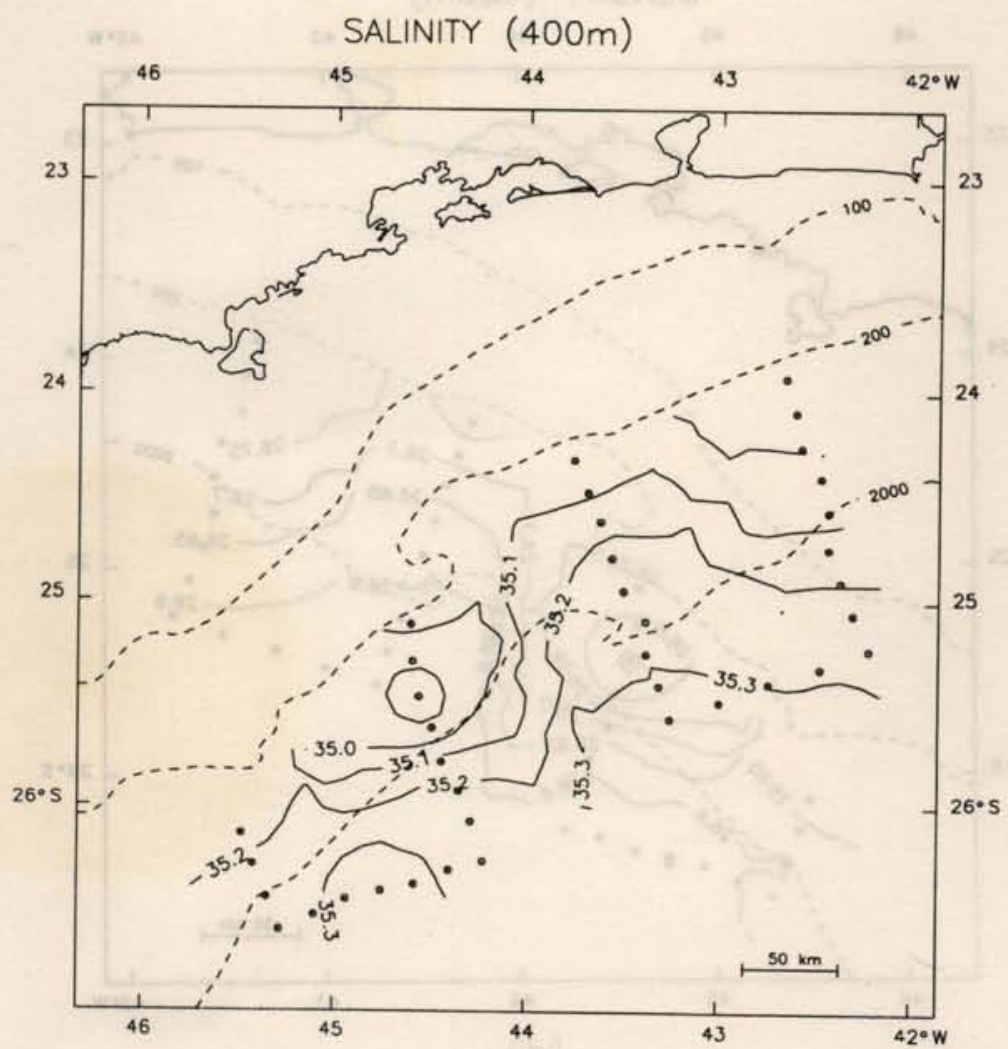

(d)

Fig. 5. Cont. 


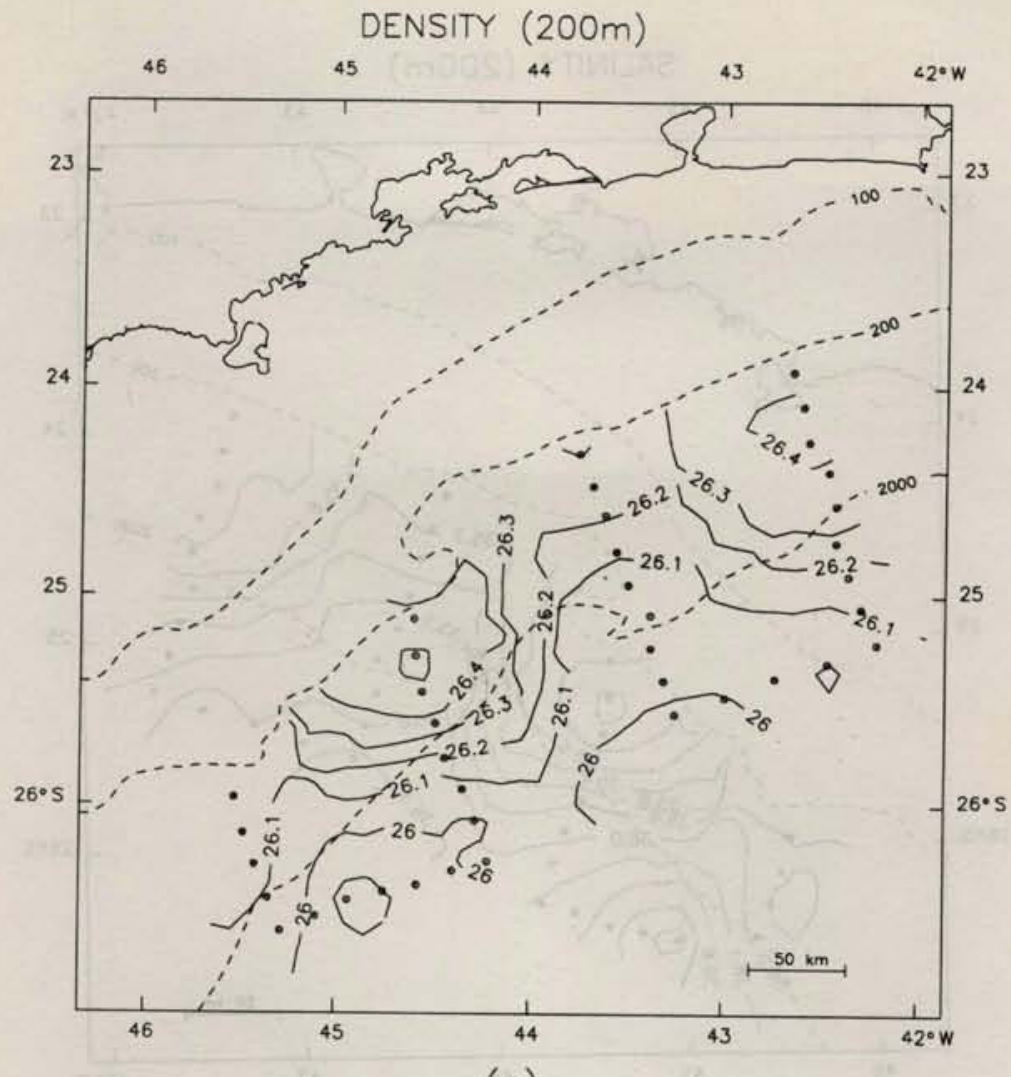

(c)

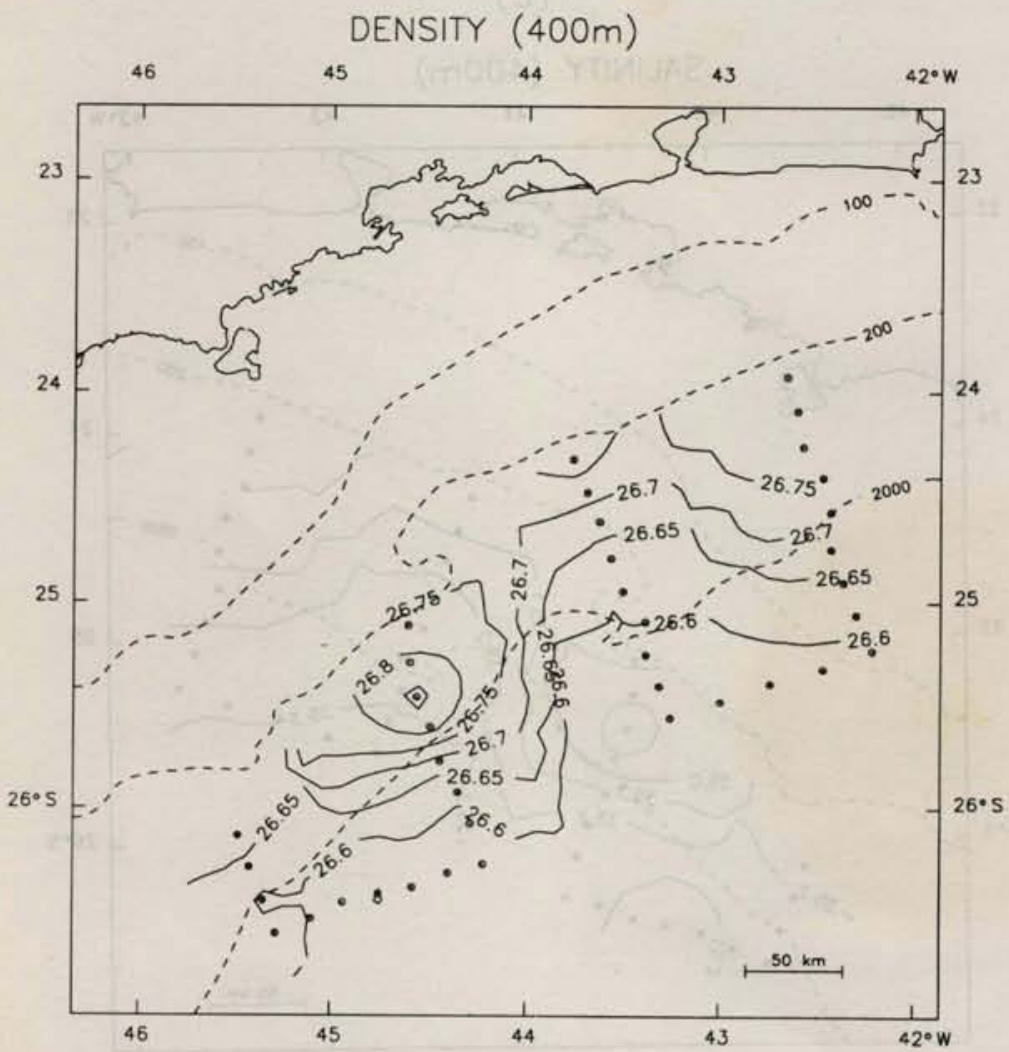

(d)

Fig. 6. Horizontal profiles for Density at (a) $0 \mathrm{~m}$; (b) $100 \mathrm{~m}$; (c) $200 \mathrm{~m}$; and (d) $400 \mathrm{~m}$. 


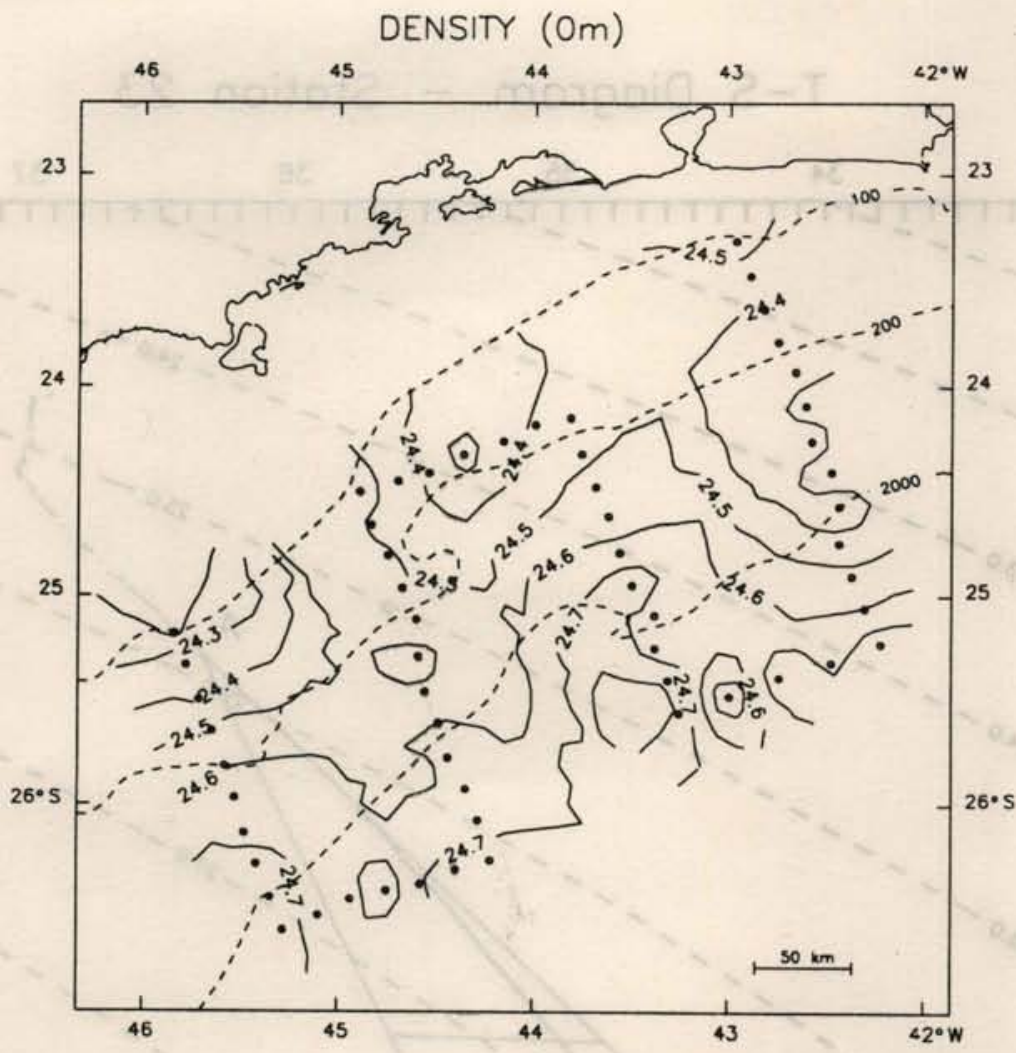

(a)

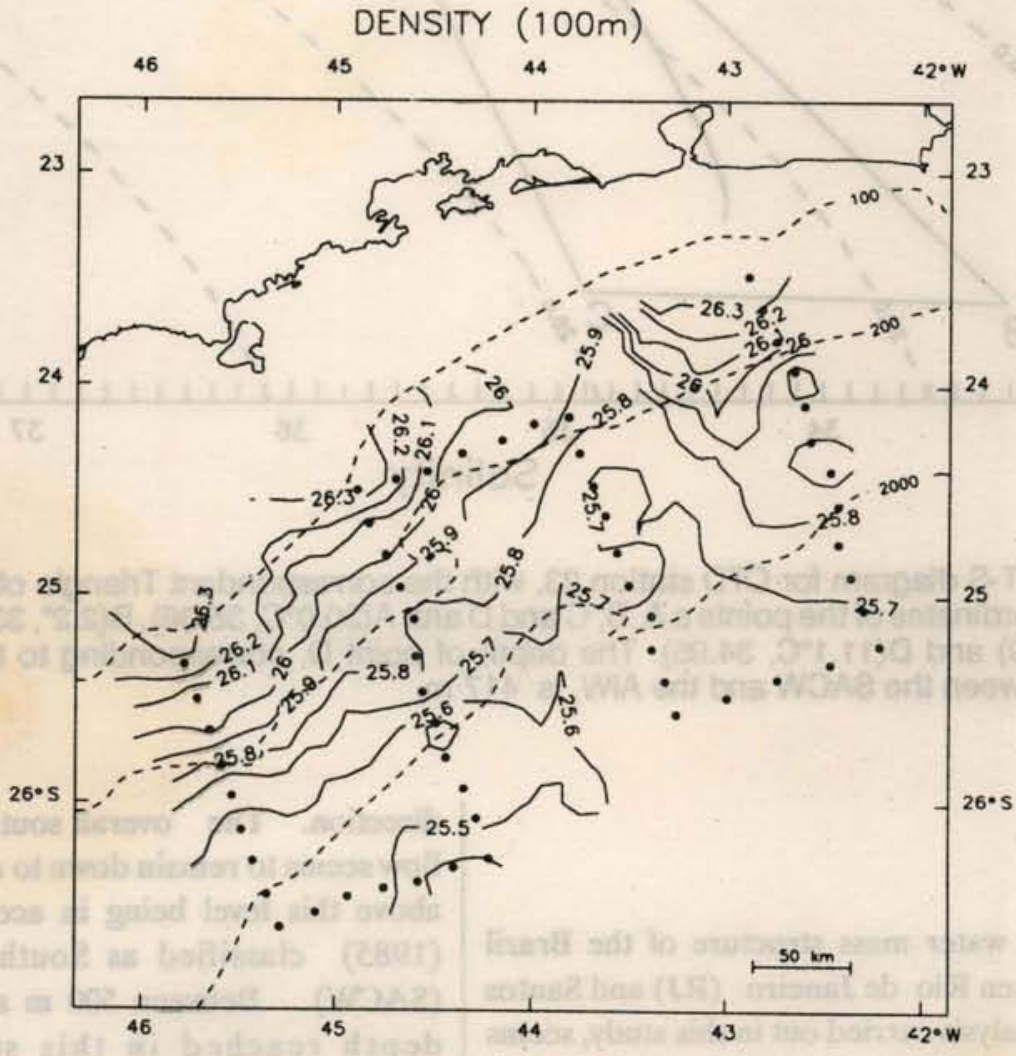

(b)

Fig. 6. Cont. 


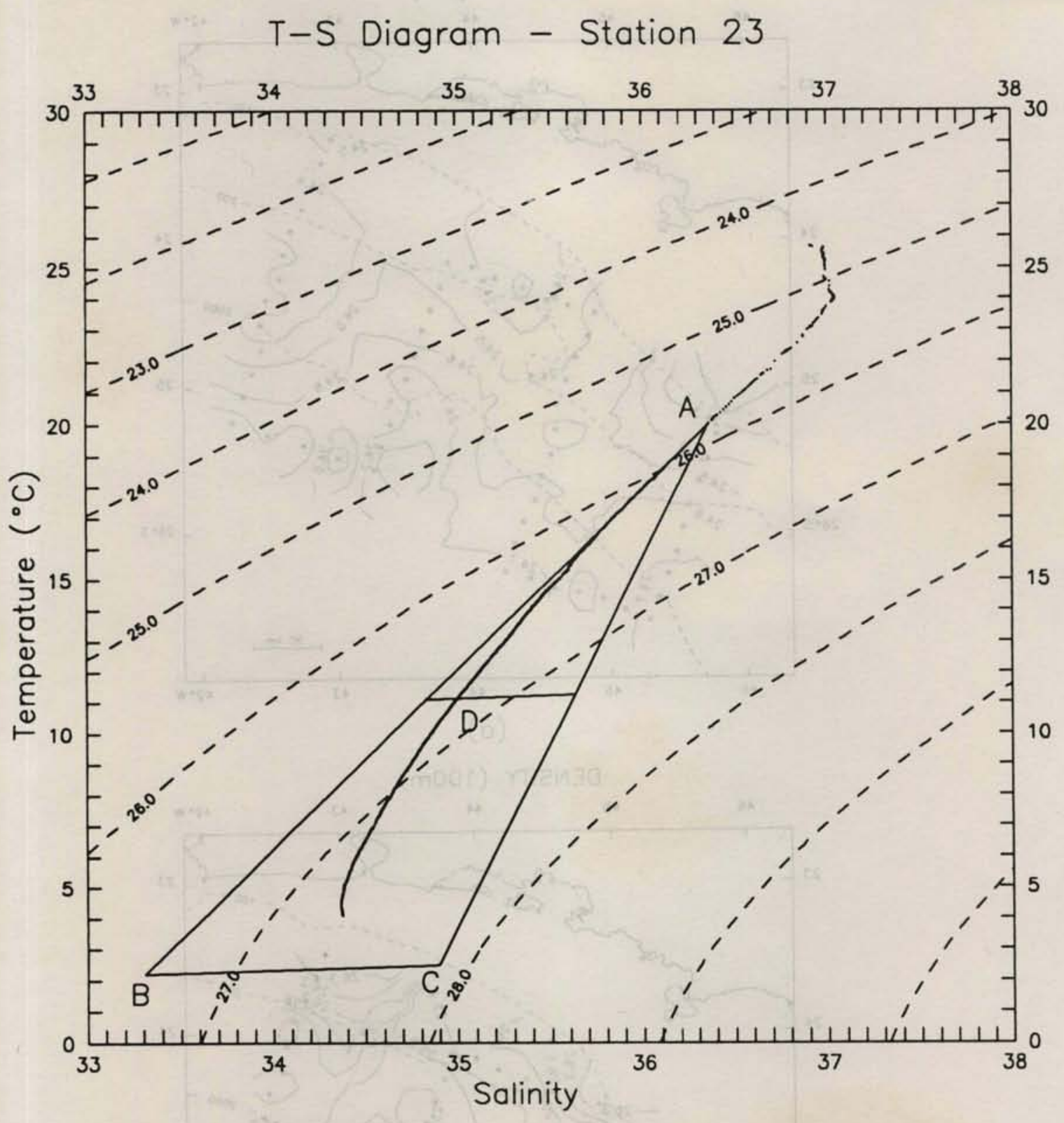

Fig. 7. T-S diagram for CTD station 23, with the correspondent Triangle of Mixing. The coordinates of the points a A, B, C and D are: $\mathrm{A}\left(20.0^{\circ} \mathrm{C}, 36.36\right), \mathrm{B}\left(2.2^{\circ}, 33.31\right), \mathrm{C}\left(2.5^{\circ}\right.$, 34.9) and $D\left(11.1^{\circ} \mathrm{C}, 34.95\right)$. The depth of point $\mathrm{D}$, corresponding to the interface between the SACW and the AIW, is $417 \mathrm{~m}$.

\section{Discussion}

The summertime water mass structure of the Brazil Current region between Rio de Janeiro (RJ) and Santos (SP), based on the analysis carried out in this study, seems to follow the same overall characteristics for the better observed Cabo Frio region, a little to the north. The uppermost $200 \mathrm{~m}$ is dominated by warm highly saline water flowing predominantly to the southwest, but with well pronounced departure from the along-isobath direction. The overall southwestward direction of the flow seems to remain down to about $500 \mathrm{~m}$, with the water above this level being in accordance to what Miranda (1985) classified as South Atlantic Central Water (SACW). Between $500 \mathrm{~m}$ and $\mathbf{9 0 0 - 9 5 0 ~ m ~ ( m a x i m u m ~}$ depth reached in this study), the water mass characteristics are those of the Antarctic Intermediate Water (AIW).

Water mass analyses based on T-S diagrams show good agreement between thermohaline structure in the 
outcropping of the thermocline in this region. The thermohaline structure also suggests the presence of a branch of the Brazil Current (or an eddy) over the continental shelf.

One final remark, which should by itself justify the publication of this article, is that the Victor Hensen cruise was the first oceanographic survey in the region studied to make use of a CTD probe. In addition to that, even using more traditional methods, the vast majority of the hydrographic cruises in this particular oceanic region covered only the continental shelf, with very few extending to regions with depths greater than $200 \mathrm{~m}$.

\section{Acknowledgments}

We wish to express our gratitude to the Secretaria da Comissāo Interministerial para os Recursos do Mar (SeCIRM), to the R/V Victor Hensen crew, to the Institute für Meereskunde an der Universität zu Kiel (IfM-Kiel) and to the Instituto Oceanográfico da Universidade de São Paulo (IOUSP). Also, we would like to thank Drs Luiz Bruner de Miranda and Affonso da Silveira Mascarenhas, for their interesting suggestions during the preparation of this manuscript.

\section{References}

DEFANT, A. 1941. Die Absolute Topographie das phys. Meeresniveaus und der Druckflächen, sowie die Wasserbewegungen im Atl. Ozean. it Meteor Werk. 6(2), 5:191-250.

EVANS, D. L.; SIGNORINI, S. R. \& MIRANDA, L. B. de 1983. A Note on the Transport of the Brazil Current. J. Phys. Oceanogr., 13:1732-1738.

EVANS, D. L. \& SIGNORINI, S. R. 1985. Vertical Structure of the Brazil Current. Nature, 315(6014):48-50.

EVENSON, A. \& VERONIS, G. 1985. Continuous Representation of Wind Stress and Wind Stress Curl over the World Ocean. J. Mar. Res., 33:131-144.
FU, L.-L. 1981. The General Circulation and Meridional Heat Transport of the Subtropical South Atlantic determined by Inverse Methods. J. Phys. Oceanogr., 11:1171-1193.

GARFIELD III, N. 1990. The Brazil Current at Subtropical Latitudes. Ph.D. Thesis, University of Rhode Island, $121 \mathrm{pp}$.

HELLERMAN, S. \& ROSENSTEIN, M. 1983. Normal monthly wind stress over the world ocean with error estimates. J. Phys. Oceanogr., 11:1093-1104.

MAMAYEV, O. I. 1975. Temperature-Salinity Analysis of World Ocean Waters. Elsevier, Amsterdam. 374pp.

MIRANDA, L. B. de 1985. Forma da Correlação T-S de Massas de Água das Regiōes Costeira e Oceânica entre o Cabo de São Tomé (RJ) e a Ilha de São Sebastiāo (SP), Brasil. Bolm Inst. oceanogr., S Paulo, 33(2):105-119.

MIRANDA, L. B. DE \& CASTRO FILHO, B. M. 1979. Condiçōes de Movimento Geostrófico das Águas Adjacentes a Cabo Frio (RJ). Bolm Inst. oceanogr., S Paulo, 28(2):79-93.

MIRANDA, L. B. de \& CASTRO FILHO, B. M. 1982. Geostrophic Flow Conditions of the Brazil Current at $19^{\circ} \mathrm{S}$. Ciencia Interamer., 22(1/2):44-48.

MIRANDA, L. B. de; MASCARENHAS, A.S.; IKEDA, Y.; RAGO, T. A. \& CACCIARI, P. L. 1985. Resultados Preliminares da Estrutura Térmica e do Campo de Velocidade Amostradas Durante o Cruzeiro Oceanográfico Transcobra III. Relatórios de Cruzeiros, série: N/Oc. "Prof. W. Besnard". 6:1-13.

SIGNORINI, S. R. 1976. Contribuição ao Estudo da Circulaçāo e do Transporte de Volume da Corrente do Brasil entre o Cabo de São Tomé e a Baía da Guanabara. Bolm Inst. Oceanogr., S Paulo, 25:157-220.

SIGNORINI, S. R. 1978. On the Circulation and the Volume Transport of the Brazil Current between the Cape of São Tomé and Guanabara Bay. Deep-Sea Res., 25:481-490.

SIGNORINI, S. R.; MIRANDA, L. B. de; EVANS, D. L.; STEVENSON, M. R. \& INOSTROZA, H. M. 1989. Corrente do Brasil: Estrutura térmica entre $19^{\circ}$ e $25^{\circ}$ e circulação Geostrófica. Bolm Inst. oceanogr., S Paulo, 37(1):33-49.

SHTOKMAN, W. B. 1946. A theory of the T-S curves as a method for studying the mixing of water mases in the sea. J. Mar. Res., 6(1):1-24 
STRAMMA, L. 1989. The Brazil Current transport south of $23^{\circ}$ S. Deep Sea Res., 36(4A):639-646.

SVERDRUP, H. U.; JOHNSON M. W. \& FLEMING, R. H. 1942. The Oceans, Their Physics, Chemistry, and General Biology. Prentice-Hall, Inc., Englewood Cliffs, N.J., 1060 pp.

WÜST, G. 1935. The Stratosphere of the Atlantic Ocean, Willian Emery, editor, Amerind Publishing, New Delhi, 1980, 112pp.

(Manuscript received 10 July 1992; revised 16 August 1993; accepted 11 August 1994) 